\title{
Exploring Social Sustainability and Economic Practices: Multi-Journal Compendium
}

\author{
Giuseppe T. Cirella ${ }^{1, * \mathbb{C}}$, Anatoliy G. Goncharuk ${ }^{2}$, Corrado lo Storto ${ }^{3} \mathbb{C}$ and Alessio Russo 4 (i) \\ 1 Faculty of Economics, University of Gdansk, 81-824 Sopot, Poland \\ 2 Department of Management, International Humanitarian University, 65009 Odessa, Ukraine; agg@ua.fm \\ 3 Department of Industrial Engineering, University of Naples Federico II, 80125 Naples, Italy; \\ corrado.lostorto@unina.it \\ 4 School of Arts, University of Gloucestershire, Francis Close Hall Campus, Cheltenham GL50 4AZ, UK; \\ arusso@glos.ac.uk \\ * Correspondence: gt.cirella@ug.edu.pl
}

Received: 18 February 2020; Accepted: 21 February 2020; Published: 25 February 2020

check for updates

\begin{abstract}
In consideration of the three pillars of sustainability, alongside the environment, social and economic dimensions interplay valuable insight into how society is molded and what key components should be considered. In terms of social sustainability, there are processes and framework objectives that promote wellbeing integral to the balance of people, planet, and profit. Economic practices consider the system of production, resource allocation, and distribution of goods and services with respect to demand and supply between economic agents. As a result, an economic system is a variant of the social system in which it exists. At present, the forefront of social sustainability research partially encompasses the impact economic practices have on people and society-with notable emphasis centered on the urban environment. Specific interdisciplinary analyses within the scope of sustainability, social development, competitiveness, and motivational management as well as decision making within the urban landscape are considered. This book contains nine thoroughly refereed contributions that interconnect detailed research into the two pillars reviewed.
\end{abstract}

Keywords: sustainability; social development; economics; wellbeing; stakeholders; competitiveness; motivational management; sustainable decision making; urban landscape; research methods

\section{Introduction}

This multi-journal compendium is made up of three special issues from Sustainability, Urban Science, and Social Sciences; it examines a broad array of research activities within two of the three pillars of sustainability [1-3]. It includes nine thoroughly refereed contributions that, respective of the environment, focus on the social and economic dimensions. Valuable discernment into how society and its key components are organized takes into account social sustainability alongside sound economic practices $[4,5]$. Social sustainability specifically pieces together the processes and framework of balancing people, planet, and profit in terms of wellbeing and future generational perspectives [6,7]. Social sustainability has been defined as the "neglected component of sustainability" [8] that incorporates both social equity and community concerns [9]. Particular importance is stressed upon community- and urban-oriented measures. Integrative economic practices intersect the economic system of production, resource allocation, and distribution of goods and services between economic agents. Economists and policymakers alike have generally examined variances of efficiency into these elemental attributes. Political debate has been, and actually still is, a principal concern of where the applied cut-off point should be in terms of government expenditure at central and local levels. The rationale of how spending cuts can offer relief, or even strengthen a country's economy, interplays 
a significant role in the modernity of economic thinking [10,11]. With respect to these developmental concerns, this book explores the utility of economic practices by way of social interaction within the bounds of society-based studies.

It is important to identify that facets of society predominately are applied within the urban setting and, hence, require urban-specific decision making. Since the world's population is rapidly increasing and will top 9.7 billion by 2050 and two thirds of the world's population will be concentrated in urban areas by 2025 [12], increasing the importance of providing not only environmental quality but livable and socially acceptable spaces [13] become paramount to healthy and educative-oriented societies. Advanced rates of urbanization coincide with global environmental degradation, increase the consumption of natural resources, habitat loss, and overall ecosystem change [14-16]. A cause-and-effect reproach from escalating global population brings to the forefront the need to re-examine how urban spaces are developed, used, and urban inhabitants interact respective of social and economic wellbeing. These benefits are referred to as nature-based solutions which-to some degree-complement umbrella-like concepts of green economics [17] and full-cost accounting [18] as well as overarching measuring tools (e.g., Human Development Index, ecological footprint, and index of sustainable functionality [19-21].

Within the framing of social sustainability, clearly a wealth of literature has been dedicated to the study of social development of what equates to "social capital, social cohesion, and social exclusion" [22]. As such, necessary goods and services at the societal level [23,24] should address "on what might be called 'higher-order' needs" [22]. As a new strand of discourse on sustainability, social sustainability comes at the response and "dominance of environmental concerns and technological solutions in urban development and lack of progress in tackling social issues" [25]. Issues such as financial austerity and public sector budget cuts as well as social degeneration at the relational level of wellbeing and development are essential concerns to contemporary societies. This book pieces together, predominately, socially oriented inquiries within a variety of studies that include an urban overtone. Exemplar economic practices are also intertwined in the latter part and complement the overall outlook of the compendium.

Dating back to 2015, a number of countries have made notable gains in meeting the Millennium Development Goals since their adoption in 2000, however, progress against these goals were-generally-inconsistent [26]. A more holistic approach for the implementation of the current Sustainable Development Goals (SDGs) is needed [27]. As a result, we should reposition social sustainability at the forefront of the SDG-dilemma since it negatively generates higher environmental impacts [28]. In view of this importance, quantitative relations between the SDGs should be well-established so that integrative policies can be implemented where possible [28]. To ensure that social sustainability does not come at the expense of economic or environmental sustainability, a balance between the different dimensions of sustainability is required [29-31]. As research findings are still not widely accepted in the policy process, it is hopeful this book will add informative expertise for policymakers as well as regional planners, that have a pivotal role, in ensuring sound sustainable development for future generations.

\section{Synopsis}

The central argument of this multi-journal compendium is to present innovative contributions that offer novel and intriguing linkages within the subject matter of social sustainability and economic practices. The book is broken down to include geographical country-specific research, i.e., from Spain, Ecuador, Ukraine, France, and Italy, and region-based studies from the Mediterranean and the European Union (EU). The collection of contributions provided a number of methods and novel approaches that add to the overall knowledge-base of scholarly and academic expertise. In accordance with MDPI's review guidelines, the contributions partook thorough, single-blinded review before being accepted for publication. The contributions are summarized and provide case study insight 
into sustainability thinking with respect to social and economic emergences. A synopsis on the book consists of five social sustainability studies followed by four economically related ones.

Diego et al. [32] examine socioeconomic factors (i.e., population structure, density, livestock farms, education, among others) within the Galician municipalities of northern Spain-an area that comprises of up to $50 \%$ of total wildfires nationally. These factors comprise of probable pre-forest fire circumstances that have a prevalent vulnerability to the local population. Linkages show that socioeconomic variables can influence fire occurrence-both positively and negatively. The study analyzes the relationship between wildfire events and socioeconomic variables to ensure best practices for territorial integrity. To this effect, a thorough examination and selection of the most relevant socioeconomic variables was carried out. Using statistics, a linear regression model was executed from wildfire data between 2001 and 2015. The resulting model allowed for an optimum socioeconomic awareness to be maintained when wildfires occur. As such, the results identified existing relational interchange between socioeconomics and wildfire events and, consequently, offer enhancement and intervention aid territory wide. The research stresses it is one of the best ways to carry out prevention action in order to reduce vulnerability to forest fire occurrences.

Wei et al. [33] look at scale-free relationships between social and landscape factors in Quito, Ecuador. The debate between urban landscapes and social activities is explored in terms of scales of observation. This study applied a hierarchical zoning technique, by examining how relationships between typical spatial landscape metrics and social indicators stand up against zoning scales. Results indicated that the estimates of both landscape heterogeneity features and social indicators significantly depend on the level of zoning scale. As a result, the mean values of the typical landscape metrics in accordance with social indicators all exhibited predictable responses to a changing zoning scale-suggesting a consistent and significant scaling relationship within multiple zoning. Quantitative methods applied to the urban spaces included deprivation and public service accessibility. The relationships between social indicators and a typical landscape aggregation metric significantly depended on scale, suggesting the importance of zoning scale decisions for analyzing these relationships is essential. The involvedness of the study also suggests complex socioecological systems in other cities, which are shaped by conflated influences of both anthropogenic and natural factors, could share a significant role in developing scale-free relationships. Moreover, the behavior challenges from the traditional modifiable area unit problem may provide mechanistic insight into the conflicts and compatibilities between human activities and human-induced land use change.

Velychko et al. [34] explore a societal-oriented case study by investigating the efficiency in higher education in Ukraine. This research spurred from the fact that Ukrainian higher educational establishments, in the global international environment, have not implemented significant positive changes since it gained state sovereignty from the Soviet Union in 1990. Progressive regulatory changes are necessary to stimulate internal university reforms within the context of European integration. The study developed organizational and methodological measures in order to increase the efficiency of scientific-pedagogical activity by using monographic, historical, comparative, generalization, formal-logical, analysis and synthesis, categorical approach, observation, interviewing, graphic, benchmarking, and forecasting. The mechanisms of utilizing re-engineering and motivational management, in the process of implementing European integration objectives, is suggested. The system of normative indices is formed to stimulate the effectiveness of the scientific-pedagogical activities of universities in terms of marketing educational services, innovation, and quality. The social development of stimulating scientific-creative activity is pre-tested and put into practice.

Muchangos and Vaughter [35] piece together a conceptual framework by focusing on gender issues in waste-related educational programs. Gender issues are presented as internal to waste management, i.e., from daily handling activities through to decision making processes. In waste educational programs, the disregard for views of and contribution by women has resulted in strategies that do not comprehensively address the waste issue, preventing long-standing and sustainable outcomes, while increasing existing gender inequities. Three critical waste matters on education and gender are identified. 
Social research explores this relationship by proposing the use of a participatory framework for gender mainstreaming in waste education. The framework included components to assess promoting the program at all its stages. The framework represented a novel theory and practical concept for waste education development-by supporting academics, practitioners, and policymakers—in the quest of achieving equitable and sustainable waste management systems society-wide.

Cruz de Carvalho et al. [36] conceptualize the use of selecting potential moss species for green roofs in the Mediterranean Basin. This socio-urban study examines green roof infrastructure by addressing the effects of climate change in urban areas. Throughout the Mediterranean Basin-where the summers radiate higher temperatures and water is scarce- the use of vascular plants to increase water consumption during warmer periods is examined. The use of mosses is presented due to their poikilohydric nature in which they respond to the environmental availability of water (i.e., completely drying out and recovering upon rehydration). Although criteria for the selection of vascular plants adapted to the Mediterranean and suitable for green roofs have been explored, new information is made available in regard to the selection of mosses based on scientific criteria. The proposed research is based on ecological preferences according to Ellenberg's [37] values and helps to define moss traits suitable for non-irrigated, nature-based green roofs tolerable to the Mediterranean climate. The main result is a table of potential candidate mosses that can be either used as standalone or in conjunction with vascular plants to decrease water usage and manage stormwater through an easily applicable selection methodology. The study, albeit technical in nature, has an underlying scope in which practitioners could utilize these advancements for best fit green infrastructure development in extreme climatic regions that endure scarce water resources.

Mazilescu and Gangloff [38] examine individual behaviors in Rouen, France, by looking at social and organizational environments of small and medium-sized enterprises (SMEs) by assigning social value scores. This social sustainability study looks at individuals that maintain allegiant behaviors. Numerous studies have highlighted the normative character of allegiance within the field of social norms and values. As such, the research questioned 170 employees on social values attributing terms of desirability and utility within the context of future colleagues (i.e., subordinate or peer). Individuals scored future colleagues in terms of an allegiance questionnaire. It was observed that desirability and utility made reference to two independent dimensions. It was also noted that there was greater severity assigned to endo-group targets (i.e., future peers) than to exo-group targets (i.e., future subordinates). The study closed by noting a rejection of rebel targets, which raised the question of the bi-dimensionality of the valuation-devaluation process.

Nyenno et al. [39] explore economic practices in terms of joint value as a measure of sea trade ports in Ukraine by using the stakeholder effect approach. The research followed an efficiency measurement within the maritime industry by assessing joint value of varying industry stakeholders. A list of factors contributing to the efficiency of the state maritime policy, as well as factors in the development of the industry, were defined and separated into four groups: infrastructure, management, marketing, and service. The joint value was analyzed for both macroeconomic and microeconomic levels and combined into a multivariate regression model - tested using Statistica 8.0. The complexity of the results, created for the maritime industry, led to a revealing conclusion that an optimum alternative to the development of the port industry suggests state modernization and corporatization by way of a port business model.

Gazzola et al. [40] research consumer empowerment in the digital economy in Italian universities. Economic practices examine the advent of the digital economy and, implicitly, of competition in the online marketplace-with respect to consumer protection approaches. Online, consumer skills are expected to be improved and the level of consumer awareness and engagement increased. As a baseline requisite, the study intended to advance and test a research model integrating five main constructs, namely: competition in the online marketplace, online consumer skills, online consumer awareness, online consumer engagement, and sustainable purchasing decisions. A total of 318 university students-a representative population of the new Millennial generation-accepted the 
invitation to participate in a questionnaire-based survey. In order to pertinently analyze the collected data, a structural equation modeling technique, based on partial least squares, was employed for the assessment of the measurement and structural model. The findings indicated that $24.4 \%$ of variance was found for sustainable purchasing decisions in which the highest influence came from the improvement of online consumer skills. The study implied that online providers should revisit their products' sustainability standards to preserve their competitive edge.

Finally, Paczoski et al. [41] piece together a debt and deficit growth rate study for post-communist EU Member States (MSs). A focalized analysis and reporting of the problems of general government debt (GGD) and government deficit (GD) and their influencing factors on economic growth rate tell the story of positive, neutral, and negative economies. Research was conducted over a 19-year period between 2000 and 2018 on all 11 post-communist MSs. Reviewed literature examined different types of GGD and GD with denoted influence on each MS's economy and government. GGD and GD increased as a result of state intervention by reacting to economic fluctuations needed in creating redistributive-related fiscal policy. A breakdown of the problems of fiscal policy is explained. Histo-geographical research was considered and a comparative examination of GGD, GD, and growth rate illustrated. In all, negative or stagnant periods revealed a general positive trend throughout the study with the exception of the world financial crisis of 2008 which marked a deteriorative period on growth rate. In the latter years of the study, MSs' economic promise signaled a high potential for renewed public finance and stability initiatives.

\section{Conclusions}

The contributions were divulged from three special issues in which each included three published articles. The source of the journals are as follows: (1) Sustainability Special Issue on "Multi-disciplinary Sustainability Research", (2) Urban Science Special Issue on "Urban Sustainability: A Smart, Compact Future in Landscape Architecture", and (3) Social Sciences Special Issue on "Measuring Efficiency Considering Efficacy, Fairness and Uncertainty: Current Trends in Methods, Practice, and Policies". The ordering of the contributions was in relation to the two themes: social sustainability and economic practices. The initial five contributions exhibit renewed ideas into social sustainability in terms of social vulnerability, scale-free relationships, managing efficiency, gender mainstreaming, and socio-urban infrastructure. The latter four engaged in economic practices with respect to social and organizational behavior of SMEs, industry stakeholders, and digital economy as well as comparative research into GGD, GD, and growth rate. These four papers focused on economic practices that closely coincide with sustainable development concerns. In particular, scholars have examined such linkages by either looking inside the organizational boundaries or outside by considering different actors relative to the economic environment. Results that have emerged from the contributions, often indicated that several variables can affect the linkage between economic practice and sustainable development-at the individual, organization, and system level—making it complex and not easily understood, e.g., employee motivation, manager leadership, organization and business environment culture (i.e., by supporting less versus additional collaboration), and shared values. The growing awareness of market customers, considering their relevance to sustainability and environmental concerns, requires companies to pay greater attention to the type of products they sell, resource consumption, and manufacturing. Scholars also illustrated how the need to pursue greater sustainability often requires the joint contribution from several entities (i.e., within the organization or from several organizations and institutions) relevant to that economic environment. Such collaboration allows for the exploitative synergies and increased integration among actors, rationalization of resource utility, creation of business value, and—finally—increased sustainability performance.

Author Contributions: Conceptualization, Investigation, Resources, Writing-original draft preparation: G.T.C.; Validation and Writing-review and editing: G.T.C., A.G.G., C.I.S., and A.R. All authors have read and agreed to the published version of the manuscript. 
Funding: This research was funded by the Polo Centre of Sustainability-Southeast Asia Office under the "Sihanoukville Social and Economic Development" (SikDev) Cambodia Project, Grant Number: SDEV101.

Acknowledgments: The editors are grateful to the reviewers for their support and critical and constructive comments. We also extend our appreciation to the editorial assistance office of MDPI for their support throughout the review and publication process of the respective journals.

Conflicts of Interest: The authors declare no conflict of interest.

\section{References}

1. Elkington, J. Towards the Sustainable Corporation: Win-Win-Win Business Strategies for Sustainable Development. Calif. Manag. Rev. 1994, 36, 90-100. [CrossRef]

2. Elkington, J. Cannibals with Forks: The Triple Bottom Line of 21st Century Business; New Society Publishers: Stony Creek, CT, USA, 1998; ISBN 1841120847.

3. Cirella, G.T.; Zerbe, S. Quizzical societies: A closer look at sustainability and principles of unlocking its measurability. Int. J. Sci. Soc. 2014, 5, 29-45. [CrossRef]

4. Shoreman-Ouimet, E.; Kopnina, H. Culture and Conservation: Beyond Anthropocentrism; Routledge: New York, NY, USA, 2016; ISBN 9780415721981.

5. Kim, M.; Xie, Y.; Cirella, G.T. Sustainable Transformative Economy: Community-Based Ecotourism. Sustainability 2019, 11, 4977. [CrossRef]

6. Eizenberg, E.; Jabareen, Y. Social Sustainability: A New Conceptual Framework. Sustainability 2017, 9, 68. [CrossRef]

7. Blanc, H.; Raymond, A. Prise en compte de la durabilité dans la représentation sociale de la croissance économique. Dév. Durable Territ. 2011, 2,1-10. [CrossRef]

8. Kandachar, P. Materials and Social Sustainability. In Materials Experience: Fundamentals of Materials and Design; Elsevier Inc.: Oxford, UK, 2013; pp. 91-103. ISBN 9780080993591.

9. Bramley, G.; Power, S. Urban form and social sustainability: The role of density and housing type. Environ. Plan. B Plan. Des. 2009, 36, 30-48. [CrossRef]

10. Goncharuk, A.G. Using the DEA in efficiency management in industry. Int. J. Product. Qual. Manag. 2007, 2, 241-262. [CrossRef]

11. Goncharuk, A.G. Enterprise performance management: A three-level approach. Int. J. Bus. Perform. Supply Chain Model. 2009, 1, 162-186. [CrossRef]

12. United Nations. World Population Prospects: The 2015 Revision, Key Findings and Advance Tables; Working Paper No. ESA/P/WP.241; UN DESA Population Division: New York, NY, USA, 2015.

13. Haberman, D.; Gillies, L.; Canter, A.; Rinner, V.; Pancrazi, L.; Martellozzo, F. The Potential of Urban Agriculture in Montréal: A Quantitative Assessment. ISPRS Int. J. Geo-Inf. 2014, 3, 1101-1117. [CrossRef]

14. Daily, G.C. Restoring Value to the World's Degraded Lands. Science 1995, 269, 350-354. [CrossRef] [PubMed]

15. McDonald, R.I.; Marcotullio, P.J.; Güneralp, B. Urbanization and Global Trends in Biodiversity and Ecosystem Services. In Urbanization, Biodiversity and Ecosystem Services: Challenges and Opportunities; Elmqvist, T., Fragkias, M., Goodness, J., Güneralp, B., Marcotullio, P.J., McDonald, R.I., Parnell, S., Schewenius, M., Sendstad, M., Seto, K.C., et al., Eds.; Springer: Dordrecht, The Netherlands, 2013; p. 755, ISBN 978-94-007-7087-4.

16. McNeill, J.R. Something New Under the Sun: An Environmental History of the Twentieth-Century World; W.W. Norton and Company: New York, NY, USA, 2000.

17. Mell, I.C.; Henneberry, J.; Hehl-Lange, S.; Keskin, B. To green or not to green: Establishing the economic value of green infrastructure investments in The Wicker, Sheffield. Urban For. Urban Green. 2016, 18, 257-267. [CrossRef]

18. Antheaume, N. Valuing external costs-from theory to practice: Implications for full cost environmental accounting. Eur. Account. Rev. 2004, 13, 443-464. [CrossRef]

19. Imberger, J.; Mamouni, E.D.; Anderson, J.; Ng, M.; Nicol, S.; Veale, A. The index of sustainable functionality: A new adaptive, multicriteria measurement of sustainability-Application to Western Australia. Int. J. Environ. Sustain. Dev. 2007, 6, 323-355. [CrossRef]

20. Cirella, G.T. Developing a Quantitative Multi-Criteria Method of Sustainability Assessment: With Application in Queensland, Australia; Griffith Library Press: Gold Coast, Australia, 2009. 
21. Cirella, G.T.; Zerbe, S. Index of sustainable functionality: Procedural developments and application in Urat Front Banner, Inner Mongolia Autonomous Region. Int. J. Environ. Sustain. 2014, 10, 15-31. [CrossRef]

22. Vallance, S.; Perkins, H.C.; Dixon, J.E. What is social sustainability? A clarification of concepts. Geoforum 2011, 42, 342-348. [CrossRef]

23. Evans, R.; Marvin, S. Researching the sustainable city: Three modes of interdisciplinarity. Environ. Plan. A 2006, 38, 1009-1028. [CrossRef]

24. Blunt, A. Cultural geography: Cultural geographies of home. Prog. Hum. Geogr. 2005, 29, 505-515. [CrossRef]

25. Woodcraft, S. Understanding and measuring social sustainability. J. Urban Regen. Renew. 2015, 8, $133-144$.

26. United Nations. Emerging Issues: Contributions of Social Development to the Transition from the Millennium Development Goals to the Sustainable Development Goals; Commission for Social Development: Brussels, Belgium, 2015.

27. SDG. United Nations Sustainable Development Goals. Available online: http://www.un.org/ga/search/view_ doc.asp?symbol=A/RES/70/1\&Lang=E (accessed on 3 May 2019).

28. Scherer, L.; Behrens, P.; de Koning, A.; Heijungs, R.; Sprecher, B.; Tukker, A. Trade-offs between social and environmental Sustainable Development Goals. Environ. Sci. Policy 2018, 90, 65-72. [CrossRef]

29. Dempsey, N.; Bramley, G.; Power, S.; Brown, C. The social dimension of sustainable development: Defining urban social sustainability. Sustain. Dev. 2011, 19, 289-300. [CrossRef]

30. UN-HABITAT. ESCAP. The State of Asian Cities 2010/11, 1st ed.; United Nations Human Settlements Programme: Fukuoka, Japan, 2010; ISBN 9789211322743.

31. Bigio, A.G.; Dahiya, B. Urban Environment and Infrastructure; The World Bank: Washington, DC, USA, 2004.

32. Diego, J.; de Rúa, A.; Fernández, M. Designing a Model to Display the Relation between Social Vulnerability and Anthropogenic Risk of Wildfires in Galicia, Spain. Urban Sci. 2019, 3, 32. [CrossRef]

33. Wei, C.; Padgham, M.; Barona, P.C.; Blaschke, T. Scale-free relationships between social and landscape factors in urban systems. Sustainability 2017, 9, 84. [CrossRef]

34. Velychko, O.; Velychko, L.; Kharytonov, M. Managing Efficiency in Higher Education: A Case of Ukrainian Universities. Soc. Sci. 2018, 7, 138. [CrossRef]

35. Muchangos, L.; dos Vaughter, P. Gender Mainstreaming in Waste Education Programs: A Conceptual Framework. Urban Sci. 2019, 3, 29. [CrossRef]

36. Cruz de Carvalho, R.; Varela, Z.; do Paço, T.A.; Branquinho, C. Selecting Potential Moss Species for Green Roofs in the Mediterranean Basin. Urban Sci. 2019, 3, 57. [CrossRef]

37. Ellenberg, H.; Weber, H.E.; Düll, R.; Wirth, V.; Werner, W.; Paulissen, D. Zeigerwerte von Pflanzen in Mitteleuropa, 2nd ed.; Goltze, Scripta Geobotanica: Göttingen, Germany, 1992; ISBN 9783884525180.

38. Mazilescu, C.A.; Gangloff, B. Value assigned to employees who preserve the social and organizational environment. Sustainability 2017, 9, 170. [CrossRef]

39. Nyenno, I.; Rekova, N.; Minakova, S. Joint Value as a Measure of Sea Trade Port Stakeholder Effect. Soc. Sci. 2019, 8, 120. [CrossRef]

40. Gazzola, P.; Colombo, G.; Pezzetti, R.; Nicolescu, L. Consumer empowerment in the digital economy: Availing sustainable purchasing decisions. Sustainability 2017, 9, 693. [CrossRef]

41. Paczoski, A.; Abebe, S.T.; Cirella, G.T. Debt and Deficit Growth Rate Reporting for Post-Communist European Union Member States. Soc. Sci. 2019, 8, 173. [CrossRef]

(C) 2020 by the authors. Licensee MDPI, Basel, Switzerland. This article is an open access article distributed under the terms and conditions of the Creative Commons Attribution (CC BY) license (http://creativecommons.org/licenses/by/4.0/). 